\title{
A new genus for Papaver sect. Meconella and new combinations in Roemeria (Papaveraceae) in Europe and the Mediterranean area
}

\author{
Enrico Banfi ${ }^{1}$, Fabrizio Bartolucci ${ }^{2 *}$, Jean-Marc Tison ${ }^{3}$, Gabriele Galasso ${ }^{1}$
}

\begin{abstract}
According to recent molecular phylogenetic studies the Papaver species belonging to $P$. sect. Argemonidium should be transferred in the genus Roemeria, and species of $P$. sect. Meconella should be treated as a distinct genus. Accordingly, the new genus Oreomecon is here established, seven new combinations are proposed and one name is typified. Furthermore, the correct names in Roemeria for the eleven, currently accepted, Papaver species in the Euro-Mediterranean area are provided, including nine new combinations.
\end{abstract}

Key words: Euro+Med, nomenclature, Oreomecon, taxonomy.

Riassunto - Un nuovo genere per Papaver sect. Meconella e nuove combinazioni in Roemeria (Papaveraceae) per l'Europa e l'area mediterranea.

In base ai recenti studi filogenetici molecolari, le specie di Papaver appartenenti a $P$. sect. Argemonidium vanno trasferite al genere Roemeria, mentre quelle di $P$. sect. Meconella devono essere trattate in un genere distinto. Di conseguenza viene qui istituito il nuovo genere Oreomecon, vengono proposte sette nuove combinazioni e viene tipificato un nome. Inoltre, vengono forniti i nomi corretti in Roemeria per le undici specie di Papaver attualmente accettate in area europeo-mediterranea, incluse nove nuove combinazioni.

Parole chiave: Euro+Med, nomenclatura, Oreomecon, tassonomia.

The phylogeny of the Papaveraceae family, in particular that concerning Papaver L. and related genera, has

\footnotetext{
${ }^{1}$ Sezione di Botanica, Museo di Storia Naturale di Milano, Corso Venezia 55, 20121 Milano, Italia.

E-mail: parajubaea@gmail.com, gabriele.galasso@comune.milano.it

${ }^{2}$ Centro Ricerche Floristiche dell'Appennino (Università di Camerino - Parco Nazionale del Gran Sasso e Monti della Laga), San Colombo, 67021 Barisciano (L'Aquila), Italia.

E-mail: fabrizio.bartolucci@gmail.com

274 Impasse du Bois de Serves, F-38540 Heyrieux, France.

E-mail: jmltison@gmail.com

* Corresponding author: fabrizio.bartolucci@gmail.com

(C) 2021 Enrico Banfi, Fabrizio Bartolucci, Jean-Marc Tison, Gabriele Galasso

Received for publication: 16 June 2021

Accepted for publication: 17 September 2021

Online publication: 23 February 2022
}

been clarified in its general lines (Kadereit et al., 1997, 2011; Carolan et al., 2006; Liu et al., 2014). The studies by Kadereit et al. (2011) and Kadereit and Baldwin (2011) showed that Stylomecon heterophylla (Benth.) G.Taylor (California, NW-Mexico) and Meconopsis cambrica (L.) Vig. (Atlantic Europe) belong to the clade of Papaver s.s., sister of the clade formed by Meconopsis Vig. + Papaver sect. Meconella Spach + Papaver sect. Argemonidium Spach + Roemeria Medik.

Regarding Meconopsis, Liu et al. (2014) note that the genus in its traditional meaning is diphyletic (clades I and V) and Grey-Wilson (2014) establishes the missing combinations for the species of clade $\mathrm{V}$, suitably separated in the genus Cathcartia Hook.f. Meconopsis cambrica, now Papaver cambricum L., was initially considered the type of the genus Meconopsis having been the first species attributed by Viguier to the genus he created, but GreyWilson (2012) then requested and obtained (Applequist, 2013; Wilson, 2016; App. III of the International Code of Nomenclature [ICN], Turland et al., 2018) the conservation of Meconopsis with a different type (M. regia G.Taylor) to definitively link the generic name to the species of Himalayan complex. The results of the phylogeny require that the species of the Alpina (Meconella) and Argemonidium sections together with those of the genus Roemeria, well represented in the Euro+Med territory, are removed from Papaver and settled in appropriate genera. "Argemonidium" (11 species) and Roemeria taken individually are paraphyletic, while together they form a monophylum which is recognized as a genus, which in this case is Roemeria.

We here propose new combinations for 9 species, since Roemeria argemone (L.) C.Morales, R.Mend. \& Romero García is already available for Papaver argemone L. and R. hispida (Lam.) Stace has recently replaced Papaver hybridum L. (Stace, 2017). The case of Papaver sect. Meconella is different because here the establishment of a new genus is necessary as no name appears available at this rank, nor can names of infrageneric rank be recovered as they lack the requirements in accordance to the ICN provisions. In particular, the section Meconella cannot be elevated to a genus without changing its name as the genus Meconella Nutt. already exists (type: $M$. oregana Nutt.) including American species of a completely different lineage. 
Roemeria Medik., Ann. Bot. (Usteri) 1(3): 15. 1792.

Type: Roemeria violacea Medik., nom. illeg. [ $\equiv R$. hybrida (L.) DC.]

= Papaver sect. Argemonidium Spach $\equiv$ Papaver sect. Argemonorhoeades Fedde, nom. illeg.

Type: Papaver argemone $\mathrm{L}$.

Note. The following treatment is in agreement with Aghababjan (2011a).

Roemeria apula (Ten.) Banfi, Bartolucci, J.-M.Tison \& Galasso, comb. nov.

bas.: Papaver apulum Ten., Fl. Neapol. Prodr. App. 5: 16. $1826 \equiv$ Papaver hybridum var. apulum (Ten.) Trautv.

= Papaver argemonoides Ces.

Roemeria argemone (L.) C.Morales, R.Mend. \& Romero García, Lagascalia 15(Extra): 184. 1988.

bas.: Papaver argemone L., Sp. Pl. 1: 506(-507). 1753.

Roemeria armenii (M.V.Agab.) Banfi, Bartolucci, J.-M. Tison \& Galasso, comb. nov.

bas.: Papaver armenii M.V.Agab., Takhtajania 1: 41(-42, fig. 4). 2011.

Roemeria davisii (Kadereit) Banfi, Bartolucci, J.-M.Tison \& Galasso, comb. nov.

bas.: Papaver argemone L. subsp. davisii Kadereit, Notes Roy. Bot. Gard. Edinburgh 44(1): 38. 1986 三 Papaver davisii (Kadereit) M.V.Agab.

Roemeria hispida (Lam.) Stace, New J. Bot. 7(1): 9. 2017.

bas.: Papaver hispidum Lam., Fl. Franç. (Lamarck) 3: 174. 1779.

= Papaver hybridum L.

Roemeria meiklei (Kadereit) Banfi, Bartolucci, J.-M.Tison \& Galasso, comb. nov.

bas.: Papaver argemone L. subsp. meiklei Kadereit, Notes Roy. Bot. Gard. Edinburgh 44(1): 38. $1986 \equiv$ Papaver meiklei (Kadereit) M.V.Agab.

Roemeria minor (Boivin ex Bél.) Banfi, Bartolucci, J.-M. Tison \& Galasso, comb. nov.

bas.: Closterandra minor Boivin ex Bél., Voy. Indes Or. [Bélanger] 4: pl. 12 fig. b. 1834-1836 $\equiv$ Papaver belangeri Boiss., nom. illeg. $\equiv$ Papaver argemone L. subsp. belangeri Takht. [1972] $\equiv$ Papaver argemone L. subsp. minus (Boivin ex Bél.) Kadereit [1986], nom. superfl. $\equiv$ Papaver argemone L. f. belangeri (Takht.) Parsa $\equiv$ Papaver minus (Boivin ex Bél.) Meikle

= Papaver desertorum Grossh.

Roemeria nigrotincta (Fedde) Banfi, Bartolucci, J.-M.Tison \& Galasso, comb. nov.

bas.: Papaver nigrotinctum Fedde (pro hybr.), Pflanzenr. (Engler) IV.104(40): 330. 1909 三 Papaver argemone L. subsp. nigrotinctum (Fedde) Kadereit

Roemeria ocellata (Woronow) Banfi, Bartolucci, J.-M. Tison \& Galasso, comb. nov. bas.: Papaver ocellatum Woronow, Izv. Kavkazsk. Muz. 11(3-4):276.1918 三Papaver pavoninum subsp. ocellatum (Woronow) Kadereit

= Papaver hybridum var. grandiflorum Boiss.

= Papaver hybridum var. microcarpum N.Busch

= Papaver ocellatum var. turcomanicum Popov

= Papaver pavoninum var. incornutum Fedde

= Papaver siculum Guss. $\equiv$ Papaver hybridum var. siculum

(Guss.) Raimondo \& Spadaro

Roemeria pavonina (Schrenk ex Fisch. \& C.A.Mey.) Banfi, Bartolucci, J.-M.Tison \& Galasso, comb. nov.

bas.: Papaver pavoninum Schrenk ex Fisch. \& C.A.Mey., Enum. Pl. Nov. [F.E.L. Fischer \& C.A. Meyer] 2: 64(-65). 1842 [22 Oct 1842].

= Papaver cornigerum Stocks

= Papaver pavoninum var. freynii Fedde

- Papaver pavoninum C.A.Mey., Index Seminum [St. Petersburg (Petropolitanus)] 9: 82. 1843 [Dec 1842 publ. after 10 Feb 1843], isonym

Roemeria virchowii (Asch. \& Sint. ex Boiss.) Banfi, Bartolucci, J.-M.Tison \& Galasso, comb. nov.

bas.: Papaver virchowii Asch. \& Sint. ex Boiss., Fl. Orient. [Boissier] Suppl.: 23(-24). 1888.

$=P$. virchowii $\mathrm{f}$. paucisetosum Fedde

- P. virchowii f. genuinum Fedde, nom. inval.

Oreomecon Banfi, Bartolucci, J.-M.Tison \& Galasso, gen. nov.

bas.:Papaversect.MeconellaSpach,Hist.Nat.Vég.(Spach)

7: 19. 1838 三 Papaver [unranked] Lasiotrachyphylla

Bernh. $\equiv$ Papaver sect. Lasiotrachyphylla (Bernh.)

Pfeiff.

Type: Papaver alpinum L.

Etymology: öpeo- (oreo-) stem of the genitive of öpos (oros), mountain, and $\mu \eta \dot{\kappa} \omega v$ (mekon), poppy.

= Papaver sect. Scapiflora Elkan, nom. illeg.

Type: Papaver nudicaule L.

Note. Papaver sect. Meconella consists of 24 (Rändel, 1974) to 30 (Carolan et al., 2006) species distributed over the entire circumboreal area, from the polar regions to the reliefs. Many of them represent geographical, topographical and local variants that differ in the combination of characters consistent at first glance (color of the petals, shape and size of the fruit, shape of the leaf divisions, development of the scape, hairiness), which, however, does not allow to draw acceptable taxonomic conclusions. The most studied species belong to the European territory (Arctic sector and southern reliefs). A phylogeny of the $P$. alpinum species complex addressed on a molecular and morphological basis (Schönswetter et al., 2009) led to the conclusion that the species of this group (11 species according to Euro+Med) represent populational expressions of a single species defined by the authors as hypervariable and which taxonomically do not have even intraspecific relevance. The most western populations (Pyrenees, Spain) are an exception for which the authors propose to maintain the rank of subspecies [with the trinomial P. alpinum subsp. lapeyrouseanum (Gutermann) Kadereit]. In the present 
transfer from Papaver to Oreomecon, last genus established here, we intend to take into consideration only the species present in Europe (native and alien) as reported in Euro+Med (Aghababjan, 2011b), as they are better known and largely phylogenetically resolved, including 5 Arctic entities and 1 South European orophyte with 2 subspecies.

Oreomecon alpina (L.) Banfi, Bartolucci, J.-M.Tison \& Galasso, comb. nov.

bas.: Papaver alpinum L., Sp. Pl. 1: 507. 1753.

= Papaver alpinum subsp. ernesti-mayeri Markgr. $\equiv$ Papaver ernesti-mayeri (Markgr.) Wraber

= Papaver alpinum subsp. tatricum A.Nyár. $\equiv$ Papaver tatricum (A.Nyár.) Ehrend.

= Papaver alpinum var. occidentale Markgr. $\equiv$ Papaver occidentale (Markgr.) H.E.Hess \& Landolt

Note. Some repertoires (eg Greuter et al., 1989; IPNI, 2021) report as authors of this combination "H.E.Hess, Landolt \& R.Hirzel"; the third volume, like all the others, of the work "Flora der Schweiz und angrenzender Gebiete" was published by all three of these authors (Hess et al., 1972). However, as specified in the title page, Rosemarie Hirzel took care of the drawings and therefore is not to be included among the authors of the nomenclatural novelties.

= Papaver aurantiacum Loisel. $\equiv$ Papaver suaveolens Lapeyr., nom. illeg.

Note. See what has been written about Oreomecon alpina subsp. suaveolens.

= Papaver corona-sancti-stephani Zapał. (published as corona Sti Stephani to be corrected in corona-sanctistephani according to Arts 23.1 and 60.14 of the ICN)

$=$ Papaver kerneri Hayek

= Papaver pyrenaicum subsp. degenii Urum. \& Jáv. $\equiv$ Papaver degenii (Urum. \& Jáv.) Kuzmanov

= Papaver rhaeticum Leresche ex Gremli

Note. Leresche is generically thanked by Gremli (1881) without the diagnosis being unequivocally associated with him. Based on Art. 46.2 of the ICN, the authors of the species are therefore to be cited as "Leresche ex Gremli”.

$=$ Papaver sendtneri A.Kern. ex Hayek

= Papaver victoris Škornik \& Wraber

Oreomecon alpina subsp. suaveolens (P.Fourn.) Banfi, Bartolucci, J.-M.Tison \& Galasso, comb. nov.

bas.: Papaver pyrenaicum subsp. suaveolens P.Fourn., Quatre Fl. France 4: 372. 1936 三 Papaver alpinum subsp. suaveolens (P.Fourn.) Rändel $\equiv$ Papaver alpinum subsp. suaveolens (P.Fourn.) O.Bolòs \& Vigo, isonym

Type (lectotype, designated here): Papaver alpinum? Lin. sommets elevés, fentes des rochers. Mail du Crystal, Cambredases, Pic de Midy, Erezlidtz, Houle Marboré, Lapeyrouse s.n [before 1813] (TLM [digital image!], bottom-right individual, Fig. 1) [herbarium acronyms follow Index Herbariorum, 2021]

$=$ ? Argemone pyrenaica L. $\equiv$ Papaver pyrenaicum (L.) Willd.

Note. Papaver pyrenaicum (L.) Willd. is based on Argemone pyrenaica L. quoted from Pyrenees ("Habitat in Pyrenaeis. Tournefort"). Since only subsp. suaveolens does exist in this region, the epithet pyrenaicum should be prioritary, if its type indeed comes from Pyrenees and belongs to $P$. sect. Meconella, but it is not designated (Jarvis, 2007). We were not able to trace in $P$ the Tournefort's original material, but, anyway, the presence of such a collection in this herbarium is very uncertain. Only a careful investigation in situ at $\mathrm{P}$ and a conservation process (likely with neotypification) will allow to fix the sense of $P$. pyrenaicum. However, in conformity with predominant usage of a name, a proposal for rejection would be easier and more useful.

- Papaver suaveolens sensu Lapeyr.

- Papaver lapeyrouseanum Gutermann, nom. inval. (published as lapeyrousianum to be corrected in lapeyrouseanum according to Art. 60.9 of the ICN)

= Papaver lapeyrouseanum Gutermann ex Greuter \& Burdet (published as lapeyrousianum to be corrected in lapeyrouseanum according to Art. 60.9 of the $\mathrm{ICN}) \equiv$ Papaver alpinum subsp. lapeyrouseanum (Gutermann ex Greuter \& Burdet) Kerguélen

= Papaver suaveolens var. endressii Asch. $\equiv$ Papaver lapeyrouseanum subsp. endressii (Asch.) Greuter \& Burdet

Note. Papaver suaveolens Lapeyr. (Lapeyrouse, 1818) is illegitimate because the author listed among the synonyms $P$. aurantiacum Loisel., a species described from Mont Ventoux (Loiseleur-Deslongchamps, 1809) that automatically typifies the name of Lapeyrouse (Art. 7.5 of the ICN). Gutermann (Gutermann et al., 1974) planned to remedy by creating a replacement name (Art. 6.11 of the ICN), P. lapeyrouseanum Gutermann. However, the latter is actually the name of a new species (Art. 58.1 of the ICN) not validly published as the type was not indicated (Art. 40.1 of the ICN). Finally, Greuter \& Burdet (Greuter, 1981) validly published the name $P$. lapeyrouseanum Gutermann ex Greuter \& Burdet. However, when Fournier (1936) re-used the final epithet at a different rank for a taxon restricted to the Pyrenees only, implicitly excluded P. aurantiacum (from Mont Ventoux). So P. pyrenaicum subsp. suaveolens P.Fourn. is not to be treated as a replacement name with the same type as $P$. suaveolens, but as the name of a new taxon with a different type (Art. 58.1 of the ICN), accompanied by an indirect reference to the previously and effectively published Latin description by Lapeyrouse (Arts. 39.1, 38.13 and 38.14 Ex. 22 of the ICN). According to Art. 7.8 of the ICN, a name of a new taxon validly published solely by reference to a previously and effectively published description or diagnosis is to be typified by an element selected from the entire context of the validating description or diagnosis. We traced in TLM two herbarium specimens collected by Lapeyrouse in several Pyrenean localities. These specimens were collected surely before 1813 as the informations on the labels were reported exactly in Lapeyrouse (1813).

Oreomecon anomala (Fedde) Banfi, Bartolucci, J.-M.Tison \& Galasso, comb. nov.

bas.: Papaver anomalum Fedde, Pflanzenr. (Engler) IV.104(40): 384(-385). 1909 三 Papaver nudicaule subsp. anomalum (Fedde) Vorosch. 

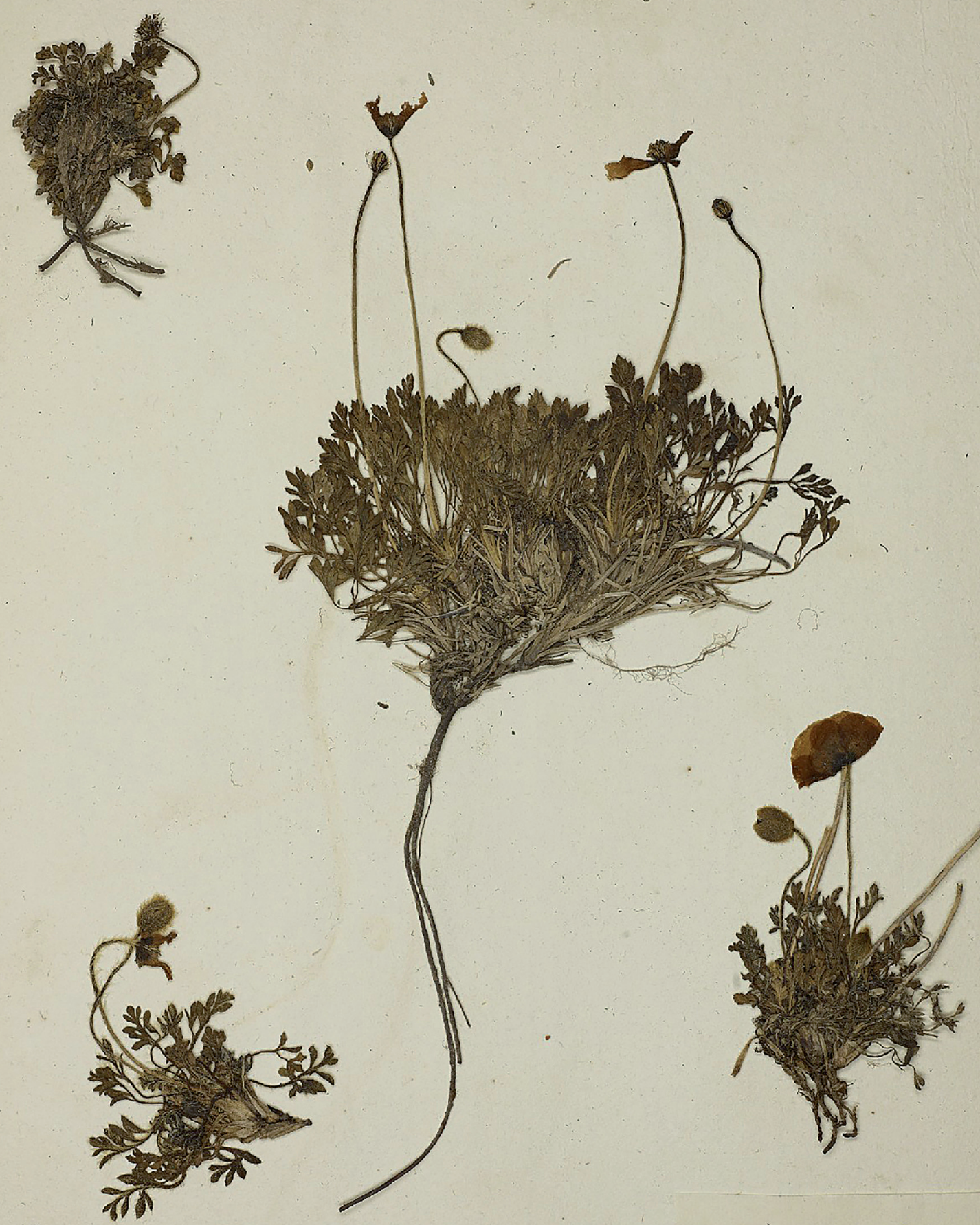

- Saparer alpiname pir

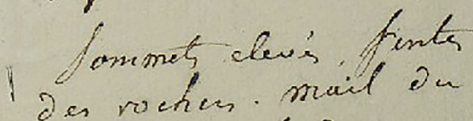

enstal Canbredases

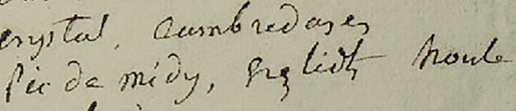
marbor:

Fig. 1 - Lectotype (bottom-right individual) of the name Papaver pyrenaicum subsp. suaveolens P.Fourn., preserved in TLM (reproduced with permission of the Herbarium, Muséum d'Histoire Naturelle de Toulouse, France). Lectotipo (individuo in basso a destra) del nome Papaver pyrenaicum subsp. suaveolens P.Fourn., conservato in TLM (riprodotto col permesso dell'Herbarium, Muséum d'Histoire Naturelle de Toulouse, Francia). 
Oreomecon crocea (Ledeb.) Banfi, Bartolucci, J.-M.Tison \& Galasso, comb. nov.

bas.: Papaver croceum Ledeb., Fl. Altaic. [Ledebour] 2: 271. 1830.

Oreomecon miyabeana (Tatew.) Banfi, Bartolucci, J.-M. Tison \& Galasso, comb. nov.

bas.: Papaver miyabeanum Tatew., Trans. Sapporo Nat. Hist. Soc. 14(4): 259. $1936 \equiv$ Papaver nudicaule var. shimshirense Miyabe \& Tatew.

Oreomecon nudicaulis (L.) Banfi, Bartolucci, J.-M.Tison \& Galasso, comb. nov.

bas.: Papaver nudicaule L., Sp. Pl. 1: 507. 1753.

Oreomecon radicata (Rottb.) Banfi, Bartolucci, J.-M.Tison \& Galasso, comb. nov.

bas.: Papaver radicatum Rottb., Skr. Kiøbenhavnske Selsk. Laerd. Elsk. 10: 455 (pl. 8 fig. 24). $1770 \equiv$ Papaver nudicaule subsp. radicatum (Rottb.) Fedde $\equiv$ Papaver nudicaule var. radicatum (Rottb.) DC.

Key to the genera Oreomecon, Papaver, and Roemeria 1 Annuals

2 Basal internode above leaf rosette robust, longer than overlying internodes, the node above producing a sort of second leaf rosette from which, when present, lateral stems branch off; capsule ovoid to linear, usually bristly

Roemeria

2 Basal internode similar to the others, leaves never forming secondary rosettes, branches arranged along the stem; capsule never linear, glabrous ...... Papaver p.p.

1 Perennials

3 Leaves also on stems; capsule glabrous .. Papaver p.p.

3 Leaves only basal; capsule bristly Oreomecon

\section{Acknowledgements}

The authors are grateful to Boris Presseq (Muséum d'Histoire Naturelle de Toulouse, France) for providing us digital images of Lapeyrouse herbarium specimens.

\section{REFERENCES}

Aghababjan M. V., 2011a - A revision of Papaver sect. Argemonidium Spach (Papaveraceae). Takhtajania, 1: 38-43.

Aghababian M., 2011b - Papaveroideae. In: Euro+Med Plantbase - the information resource for Euro-Mediterranean plant diversity. <http://ww2.bgbm.org/EuroPlusMed/> (retrieved on 30 January 2021).

Applequist W. L., 2013 - Report of the Nomenclature Committee for Vascular Plants: 65. Taxon, 62 (6): 1315-1326. <https://doi.org/10.12705/626.49>

Carolan J. C., Hook I. L., Chase M. W., Kadereit J. W. \& Hodkinson T. R., 2006 - Phylogenetics of Papaver and related genera based on DNA sequences from ITS nuclear ribosomal DNA and plastid trnL intron and trnL-F intergenic spacers. Annals of Botany, 98 (1): 141-155. <https://doi.org/10.1093/aob/mcl079>
Fournier P. V., 1936 - Les quatre flores de la France. Ed. 1. Haute-Marne, Poinson-les-Grancey, 4: 257448.

Gremli A., 1881 - Exkursionsflora für die Schweiz. Nach der analytischen Methode. $4^{\text {th }}$ ed. J. J. Christen, Aarau.

Greuter W. (ed.), 1981 - Med-Checklist Notulae, 3. Willdenowia, 11 (1): 23-43.

Greuter W., Burdet H. \& Long G., 1989 - Med-Checklist. Conservatoire et Jardin botaniques de la Ville de Genève, Genève, 4.

Grey-Wilson C., 2012 - (2061) Proposal to conserve the name Meconopsis (Papaveraceae) with a conserved type. Taxon, 61 (2): 473-474. <https://doi.org/10.1002/ tax.612026>

Grey-Wilson C., 2014 - The genus Meconopsis: blue poppies and their relatives. Royal Botanic Gardens, Kew.

Gutermann W., Ehrendorfer F. \& Fischer M., 1974 - Neue Namen und kritische Bemerkungen zur Gefäßpflanzenflora Mitteleuropas. Österreichische Botanische Zeitschrift, 122 (4) (1973): 259-273.

Hess H. E., Landolt E. \& Hirzel R., 1972 - Flora der Schweiz und angrenzender Gebiete. Birkhäuser, Basel, Stuttgart, 3.

Index Herbariorum, 2021 - Index herbariorum. The New York Botanical Garden. <http://sweetgum.nybg.org/ science/ih/> (retrieved on 2 February 2021).

IPNI, 2021 - International Plant Names Index. The Royal Botanic Gardens, Kew, Harvard University Herbaria \& Libraries and Australian National Botanic Gardens. <http://www.ipni.org> (retrieved on 2 February 2021).

Jarvis C., 2007 - Order out of chaos: Linnaean plant names and their types. The Linnean Society of London and the Natural History Museum, London.

Kadereit J. W. \& Baldwin B. G., 2011 - Systematics, phylogeny, and evolution of Papaver californicum and Stylomecon heterophylla (Papaveraceae). Madroño, 58 (2): 92-100. <https://doi.org/10.3120/0024-963758.2.92>

Kadereit J. W., Schwarzbach A. E. \& Jork K. B., 1997 The phylogeny of Papaver s.l. (Papaveraceae): polyphyly or monophyly? Plant Systematics and Evolution, 204 (1-2): 75-98. <https://doi.org/10.1007/ BF00982533>

Kadereit J. W., Preston C. D. \& Valtueña F. J., 2011 - Is Welsh poppy, Meconopsis cambrica (L.) Vig. (Papaveraceae), truly a Meconopsis? New Journal of Botany, 1 (2): 80-88. <https://doi.org/10.1179/204234811 X13194453002742>

Lapeyrouse P. de, 1813 - Histoire abrégée des plantes des Pyrénées. Bellegarrigue, Tolouse.

Lapeyrouse P. de, 1818 - Supplément a l'Histoire Abrégée des Plantes des Pyrenées. Bellegarrigue, Tolouse.

Liu Y.-C., Liu Y.-N., Yang F.-S. \& Wang X.-Q., 2014 Molecular phylogeny of Asian Meconopsis based on nuclear ribosomal and chloroplast DNA sequence data. PLOS ONE, 9 (8): e104823. <https://doi.org/10.1371/ journal.pone.0104823> 
Loiseleur-Deslongchamps J. L. A., 1809 - Suite de la Notice sur les plantes à ajouter à la Flore de France (Flora Gallica), avec quelques corrections et observations. Journal de Botanique, rédigé par une société de botanistes, 2 (6): 321-370.

Rändel U., 1974 - Beiträge zur Kenntnis der Sippenstruktur der Gattung Papaver L. sectio Scapiflora Reichenb. (Papaveraceae). Feddes Repertorium, 84 (9-10): 655-732. <https://pdfslide.net/documents/ beitraege-zur-kenntnis-der-sippenstruktur-der-gattung-papaver-l-sectio.html> <https://doi.org/10.1002/ fedr.19730840903>

Schönswetter P., Solstad H., Escobar García P. \& Elven R., 2009 - A combined molecular and morphological approach to the taxonomically intricate European mountain plant Papaver alpinum s.l. (Papaveraceae) - taxa or informal phylogeographical groups? Taxon, 58 (4): 1326-1343. <http://www.jstor.org/stable/27757020> $<$ https://doi.org/10.1002/tax.584020>

Stace C. A., 2017 - New combinations in six genera of the British flora. New Journal of Botany, 7 (1): 9-10. $<$ https://doi.org/10.1080/20423489.2017.1344044>

Turland N. J., Wiersema J. H., Barrie F. R., Greuter W., Hawksworth D. L., Herendeen P. S., Knapp S., Kusber W.-H., Li D.-Z., Marhold K., May T. W., McNeill J., Monro A. M., Prado J., Price M. J. \& Smith G. F. (eds.), 2018 - International Code of Nomenclature for algae, fungi, and plants (Shenzhen Code) adopted by the Nineteenth International Botanical Congress Shenzhen, China, July 2017. Regnum Vegetabile, 159: 1-254. <https://doi.org/10.12705/Code.2018>

Wilson K. L., 2016 - Report of the General Committee: 14. Taxon, 65 (4): 878-879. <https://doi. $\operatorname{org} / 10.12705 / 654.15>$ 